\title{
The impact of financial depth on poverty in Egypt
}

\author{
Dr. Essam El-Sayed Abdel-Raouf
}

Economics Teacher

Faculty of Commerce -Zagazig University

\section{Mahmoud Rabea}

Teaching assistant at the Department of Economics

Faculty of Commerce -Zagazig University

Journal of Business Research

Faculty of Commerce -Zagazig University

Volume 43 - Issue 4 October 2021

link: https://zcom.journals.ekb.eg/ 


\begin{abstract}
:
This study deals with the linkages between financial depth and poverty reduction in Egypt using data for the period of 1990-2015.The study applied last square method (OLS) to examine impact of financial depth on poverty reduction. The study depends, in expressing its dependent variable, which is the level of poverty, on two original variables: The poverty gap, and the percentage of the number of actual poor in the population, at the poverty line of \$ 1.90 per day, according to 2011 purchasing power parity. As for the independent target variable we have which is financialdevelopment, the study will depend on three variables proxy to express on the level of financial development, in order to verify the robustness and reliability of the results, namely, domestic credit to the private sector (\% of GDP), and financial depository bank assets to GDP (\%), in addition to bank credit for bank deposits (\%). Our results show evidence of cointegration which confirms the presence of long run relationship between financial deepening, economic growth, and poverty reduction.
\end{abstract}

Key words: financial development; financial depth; poverty 


\section{Introduction:}

The role of the financial sector in the economy is one of the most significant of current theoretical and empirical economics. It is believed that the financial sector represents a significant factor reflecting the current and future ingredients in the growth of any economy.

Financial development plays a key role in the finance-growth nexus. Although the Egyptian financial sector has surged up in the last decade, it remains relatively small and under-performing it's potential ${ }^{1}$. Recently, there has been an increasing attention to financial development and its impact on economic performance. According to the World Bank, financial development is defined as overcoming costs incurred in the financial system. Hence, the term "Financial development" refers to the improvements in the quality and range of financial services provided to relevant stakeholders (World Bank, 2013).

Egyptian Financial sector is the set of institutions, markets, instruments, and the legal and regulatory framework that allow transactions to be made by extending credit. Basically, financial sector development is about reducing "costs" incurred in the financial system. Overcoming the costs of acquiring information, making transactions, and enforcing contracts resulted in the evolution of financial contracts, markets, and intermediaries. Thus,financial sector development occurs when financial instruments, markets, and intermediaries relieve the effects of information, enforcement, and transactions costs (World Bank, 2013).

\footnotetext{
1 Egyptian financial sector contributes about $6 \%$ to GDP in 2017, while this sector represents about $20 \%$ of GDP in OECD countries.
} 
Financial development has received considerable attention overtime. The theoretical and empirical literature has reached a consensus regarding the relationship between financial development and economic growth;however, the causality direction debate is still standing. The structure of the financial sector could be bank-based or market-based, and this classification is vital for two reasons; 1- first, to identify the potential impact on investment and economic growth. Second, to know and determine the transmission mechanism of different policies.

Economists have argued that, even if a well-functioning financial system does not directly enhance poverty reduction, it does by promoting and enhancing economic growth. Theoretical and empirical literature shows that financial development can affect poverty both indirectly and directly. Indirectly, through its positive impact on growth, directly, financial system development, wide the access to financial services for the poor.

Analyzing the Egyptian financial sector necessitates considering the special features of the Egyptian economy to determine a real and prudent relationship between financial development and Economic growth. Thus,more concentration is paid to the Egyptian economy to identify the characteristics and structure of the financial sector. Egyptian economy has experienced peaks and trough by passing through several economic policies from intervention and control over market to "open market" economy. Thus, the study analyze both pre-and post-reform periods ${ }^{2}$

\footnotetext{
${ }^{2}$ The economic reform in 1990 and structural adjustment program (ERSAP)
} 
The analysis of the financial sector is beneficial. First, to determine whether the structure of the financial sector is bank-based or market-based. Since a bank-based financial sector helps in mobilizing savings, financing small and medium enterprises (SMEs), and granting credit. While in a market-based financial sector, almost huge and big corporates funded and financed through the stocks market, which is worthy for global corporations for the large, neededcapital that may be difficult to be obtained by banks only. However, the market-based financial sector can ease subject and affected by financial crises. In addition, this investment mostly is not a long-run investment. Second, identifying orientation is beneficial, since the role played by the government in allocating credit has direct and indirect effects on investments in the short and long run.

The key issues here can be represented through three major questions: first, is there a relationship between financial development and economic growth rate in Egypt? Second, shall Egypt promote financial deepening and financial inclusionto reducepoverty? Third, how can the financial sector be enhanced to increase growth?

\section{Literature Review:}

The financial sector is one of the most important sectors, which builds the structure of an economy along with other sectors. The importance of the financial sector came from its role in the economy, and it considers one of the main service sectors. The role of the financial sector is essential as it facilitates mobilizing savings, facilitates the exchange of goods and services, and finances for investment in the other sectors of the economy. 
The relationship between the financial sector development and poverty reduction through economic growth received a voluminous concern over time involving both the direction of causality and the existence of the relationship. This relationship has exposed to a lot of controversy on either empirical or theoretical bases.

One of the most highly researched topics in development economics is the connection between the operation of the financial system and economic growth.Many of the scholarly papers have been written to investigate and conceptualize how the development and structure of an economy's financial sector affect capital accumulation, domestic savings, technological innovation, and income growth, or vice versa; and to empirically test these relations including identifying their relative importance and the directions of the causality using cross-country, country-specific, and industry-, firm-, and project-level data.

The finance-growth nexus can be got back to (Bagehot, 1873). He introduced a simple relationship between finance and economic growth, where the development of money markets leads to increase capital flows through highinterest rates. He expressed the connection between financial development and economic growth by using the concept of "loanable capital" which made trade growth, as banks can create credit. He highlighted the function of productive funds in improving innovation and future growth (Arestis, 2005). Bagehot's contribution was challenged by the classic's view of neutrality of money, in which the money supply has no effect on the real variable in an economy. 
Financial sector development has direct poverty reduction affects. Several empirical studies examined a more direct relationship between financial sector development and inequality and poverty reduction (e.g., Beck, Demirgüç-Kunt and Levine 2004; Clarke, Xu and Zou 2003; Honohan 2004a; Li, Squire, and Zou 1998). Cross-country evidence pointing to the poverty reduction impact of financial sector development is well established and widely accepted, despite methodological issues related with cross-country analyzes. Honohan (2004a), for example, showed a robust impact of financial depth (measured as the ratio of private credit to GDP) on headcount poverty incidence (based on both the \$1- and \$2-a-day poverty lines). The regression results showed that a 10 percentage-point increase in the ratio of private credit to GDP would lead to a 2.5-3.0 percentage point reduction in poverty (Honohan 2004a). Given that per capita GDP is controlled in the analysis, the results show that a direct relationship between financial development and poverty reduction exists independent of the indirect effect through growth. Likewise, using data for 58 developing countries over 1980 to 2000, Beck, Demirgüç-Kunt, and Levine (2004) showed that countries with well- developed financial intermediaries (measured as the ratio of private credit to GDP) experience a faster decrease in both poverty and income inequality by disproportionately boosting the incomesof the poor. Their results are robust to controlling for potential reverse causality. They also hold even when controlling for the average rate of economic growth, which suggested that financial development alleviates poverty beyond its effect on aggregate growth.

These studies emphasized the earlier findings of Li, Squire, and Zou (1998) that financial depth (measured as the ratio of broad money supply [M2] to 
GDP) related with lower inequality andhigher income of the lower $80 \%$ of the population (i.e., the poor majority) using data for 49 developed and developing countries over 1947 to 1994 . The regression results suggested that a one standard deviation increase in financial depth would cause an increase of US $\$ 3,000$ in the incomes of the poor but only an increase of US\$1,600 in the incomes of the rich. Claessens and Feijen (2006) examined whether financial sector development played any role in achieving Millennium Development Goal. They provided robust evidence that financial development and greater access to financial services lead to income growth, a reduction in poverty, better health, and education.

The most significant channel through which financial sector development directly influences poverty is increased access to financial services. Empirical studies suggested that firms' and households' access to financial services increased with financial development (Beck, Demirgüç-Kunt, and MartinezPeria 2007). Finance can facilitate transactions, reduce the costs of remitting funds, and provide the opportunity to accumulate assets and for income smoothing. Financial services such as savings and insurance can also support firms and households deal with economic shocks and reduce their vulnerability to adverse situations, thus alleviating the risk of falling into poverty (Claessens and Feijen 2006). Based on panel dataset for 172 countries for 1950 to 1960, 1970, 1980, 1990 and 1995, Dehejia and Gatti (2002) found that an increase in access to credit reduced the extent of child labor. 


\subsection{Keynesian Monetary Model}

Keynes proposed his new thoughts about the role of money in the economy in 1936. The key argument of Keynes and in contrast to classical economists, is that, aggregate demand (spending of money) rather than wages, is the determinant of employment due to its effect on investment.

Keynes suggested that the interest rate is the main determinants of money demand. According to Keynes, demand for money or the "liquidity Preference", has three basic motives: transaction ${ }^{3}$, precautionary, and speculative motives. At speculative motive, he confirmed the inverse relationship between asset's price and interest rate (Keynes, 1936), which was a fundamental step in formulating a relationship between money demand and investing in financial assets (Elazhary, 2018).

Moreover, Keynes also concluded that, saving is basically depend on income rather than the interest rate. So, in the case of excessive savings, he argued that, market has an inelastic demand and supply for loanable funds which make supply and saving curves steep. Therefore, their response to a fall in interest rate would be weak. Thus, nominal interestrates cannot fall belowzero, where economy put a ceiling rate to avoid "liquidity trap" (Elazhary, 2018).

Keynes pointed out that business cycle instability is attributed mainly in altering consumption and investment caused by interest rate fluctuations contrary to Schumpeter. Therefore, fiscal policy intervention is a prerequisite

\footnotetext{
${ }^{3}$ Further classified as the "income motives", and the "business motive".

${ }^{4}$ Liquidity trap, is a situation introduced by Keynes in which individuals are not induced to buy more bonds or to keep their original bonds, interest rate would not be affected by increased money supplywhich would be ineffective in this situation-since money demand curve is steep.
} 
to restore financial stability. Thus, Keynes is one of the proponents of financial repression ${ }^{5}$ (Chaiechi, 2014)

\subsection{Neoclassical Theory}

\subsubsection{Tobin's Model of Monetary Growth 1965}

James Tobin 1965 in his model of money and growth follows Solow's growth model. Solow's model in 1956 implies that savings translated automatically to accumulate physical capital where saving is a fixed percentage of income, which is considered as an assertion of Say's law (Elazhary, 2018).

Tobin had integrated monetary variables into Solow's model to analyze its effect on real variables. Such an inclusion to a "non-monetary" model could interpret the long-term relation between capital intensity and the money supply to determine the optimum level of money supply for maximizing longrun growth (Tutulmaz, 2014). Also, Tobin had supported financial market repression to enhance economic growth, where repressed financial markets would decrease money demand to increase productive capital. This reduction in the demand for money was stimulated by increasing the opportunity cost of holding money, which would affect capital/labor ratio positively (Fry, 1997; and Eschenbach, 2004).

\subsection{The Egyptian Case Studies}

Several literatures (Hussein, 1999; Bolbol, et al., 2005; Abu-Bader \& AbuQarn, 2008; Hosny, 2012; Kamal, 2013; Abosedra, et al., 2015) that have been applied on Egypt showed that the causality directions runs from finance

5 Refers to the procedures by which governments channel funds to themselves as a form of debt reduction, e.g. directing credit, interest rate caps and ceiling, governmental control over financial institutions. 
to growth. on the other hand, other literature (Elsayed, 2013) confirmed that causality direction runs from growth to finance. While, (Alawad\&Harb, 2005; Abu-Bader \& Abu-Qarn, 2008) affirmed the existence of mixed results and bidirectional causality, respectively.

- Hussein, 1999 investigated the hypothesis of financial liberalization school in increasing interest rates to its efficient point. He confirmed that the development of the financial sector will impact the economic growth positively. Furthermore, the interest rate has a mixed effects on the real income. Thus, he suggested that developing financial sector could be achieved through developing stock market rather than liberalizing interest rate.

- Bolbol, et al., 2005 introduced a more detailed analysis of the financial sector where the banking sector as well as the capital market were covered. The analysis results indicated that the banks development positively affected total factor productivity (TFP) during 1979-2002, while market development have a more effect on TFP growth. The results also indicated that the financial structure is dominant by the bank-based structure whilst developing marketbased structure will impact more to economic growth particularly with the privatization procedures.

- Hosny, 2012 examined the relationship between financial development represented by several banking sector measures and economic growth during the period 1961-2009. Hosny concluded that financial development has a positive impacts on economic growth in both short-run and long-run which support the supply leading hypothesis. The same results almost has been introduced by (Kamal, 2013) as she concluded that for the period from 1988- 
2012 there was unidirectional causality that runs from banking sector development to economic growth, using Vector Auto Regression framework. She also concluded that the stock market development is not linked to economic growth (Elazhary. 2018).

- Abosedra, et al., 2015 investigated a trivariate causality between financial development, economic growth, and poverty. They found that financial development affect poverty reduction in the long run directly through increasing financial access to poor people, and indirectly by increasing economic growth.

- Abu-Bader \& Abu-Qarn, 2008 investigated the impact of financial development on economic growth on economic growth. The results support their assumption of positive impact of investment efficiency on economic growth. They recommended developing financial sector and strengthen its relationship with the real sector, actually by enhancing financial liberalization.

- $\quad$ Elsayed, 2013 introduced various results for the finance-growth nexus in Egypt. He confirmed that the causality direction supports the demand following hypothesis in the long-run. Furthermore, economic growth mainly derived from stock market development.

\section{Model Specification and characterization of variables:}

To achieve the goal of the study, which is an attempt to measure the impact of financial depth on poverty levels in Egypt, the applied study will depend on annual time series data for Egypt during the period (1990-2015) with a total of 26 observations based on the availability of poverty data in Egypt. And these variables were obtained from the World Bank (WB), Global 
Financial Development Database (GFD), in addition to the United Nations Development Program (UNDB) and Freedom House.

The study depends, in expressing its dependent variable, which is the level of poverty, on two original variables: The poverty gap, and the percentage of the number of actual poor in the population, at the poverty line of $\$ 1.90$ per day, according to 2011 purchasing power parity. As for the independent target variable we have which is Financial Development, the study will depend on three variables proxy to express on the level of financial development, in order

to verify the robustness and reliability of the results, namely; Domestic credit to the private sector (\% of GDP), and financial depository bank assets to GDP (\%), in addition to bank credit for bank deposits (\%).

\section{- Hypothesis of the study:}

Accordingly, the studyhypothesis can be concluded as follows:

\section{"There is a negative and significant impact of financial depth on the level of poverty in Egypt".}

And branched from this hypothesis the following sub-hypotheses:

- There is a negative and significant impact of domestic credit to the private sector as a percentage of GDP on the poverty gap, and the percentage of the number of actual poor in the population in Egypt.

- There is a negative and significant impact of the ratio of deposit bank assets to GDP on the poverty gap, and the percentage of the number of actual poor in the population in Egypt.

- There is a negative and significant effect of the ratio of bank credit to bank deposits on the poverty gap, and the percentage of the number of actual poor in the population in Egypt. 
Likewise, the signs of the variables of the level of inflation, trade openness, and government spending are expected to be positive at the level of poverty in Egypt, while the sign of the GDP per capita variable is expected to be negative at the level of poverty, according to the economic theory, which is supported by the signs of the correlation matrix.

Finally, aboutcontrolling variables or other explanatory variables, they were congruent with economic theory and previous studies, which presented a wide range of variables affecting poverty, such as inflation, trade openness, level of human development, dependency ratio, GDP per capita, level of government spending, Institution quality, Gini coefficient, population growth rate, etc. However, due to the decrease in the number of study years (26 observations), which makes it difficult to include all these variables explaining poverty in the current study model, and accordingly, the most important variables affecting poverty were chosen on which previous studies were unanimously agreed, namely the level of inflation, the level of trade openness, and the level of GDP per capita, and finally the level of government spending.

Hence, the study model can be formulated in its simplest form in a linear form as follows:

$$
\begin{aligned}
& \text { Poverty }_{t}=\beta_{0}+\beta_{1} F_{t}+\beta_{2} \text { Inflation }_{t}+\beta_{3} \text { Openness }_{t} \\
& \quad+\beta_{4} \text { GDP }_{\text {per capita }_{t}}+\beta_{5} \text { Gov. Exp }_{t} \\
& \quad+u_{t}
\end{aligned}
$$

Where Poverty represents the dependent variable, which is the level of poverty in Egypt, which will be expressed either by using the poverty gap or the ratio of the poor to the population. While $(\boldsymbol{F D})$ represents the level of 
financial development in Egypt, which will be expressed using three proxy variables as previously explained. While $\left(\boldsymbol{\beta}_{\mathbf{2}}\right),\left(\boldsymbol{\beta}_{\mathbf{3}}\right),\left(\boldsymbol{\beta}_{\mathbf{4}}\right),\left(\boldsymbol{\beta}_{\mathbf{5}}\right)$ in the model express the coefficients of the control economic variables used in the model respectively, $\boldsymbol{t}$ expresses the time used in the study (1990-2015), while $\boldsymbol{\beta}_{\mathbf{0}}$ expresses the equationconstant,andfinally $\boldsymbol{u}_{\boldsymbol{t}}$ indicates the error term.

Tables (1) and (2) show a general statistical description of the study variables and the correlation matrix between them respectively.Table (1) below presents a brief statistical summary of all the variables included in the study model, while Table (2) below presents the correlation matrix between the variables of the study model, and here we notice from the correlation coefficients between the independent variables with the two dependent variables (in the first and second column) presence of a negative correlation between Financial development variables with poverty levels in Egypt, which may indicate a possible negative impact of financial development on poverty in regression models, since these bivariate correlations allow us to first verify the assumed relationships. We also note that the most variable related to the poverty gap in Egypt was the level of trade openness (70.9\%), followed by the level of inflation $(61.5 \%)$, then the level of GDP per capita (-60.5\%), then the ratio of bank credit to bank deposits (-49.9\%). Then, the ratio of deposit bank assets to GDP (-45.9\%), then the ratio of domestic credit provided to the private sector to GDP (-30.6\%) and finally the level of government spending $(-22.6 \%)$. 
Table (1): General Descriptive statistics of the variables

\begin{tabular}{|c|c|c|c|c|}
\hline$O b s .=26$ & Mean & Std. Dev. & $\begin{array}{l}\text { Minimu } \\
\mathrm{m}\end{array}$ & $\begin{array}{l}\text { Maximu } \\
\mathrm{m}\end{array}$ \\
\hline \multicolumn{5}{|l|}{ Dependent Variables: } \\
\hline Poverty gap at $\$ 1.90$ a day (2011 PPP) (\%) & 0.5366 & 0.2225 & 0.2 & 1.1 \\
\hline $\begin{array}{l}\text { Poverty headcount ratio at } \$ 1.90 \text { a day } \\
(2011 \text { PPP) (\% of population) }\end{array}$ & 3.7406 & 1.6115 & 1.3 & 7.4 \\
\hline \multicolumn{5}{|l|}{ Independent Variable: } \\
\hline $\begin{array}{l}\text { Domestic credit to private sector (\% of } \\
\text { GDP) }\end{array}$ & 38.204 & 11.869 & 22.27 & 54.931 \\
\hline Deposit money banks' assets to GDP (\%) & 69.422 & 8.0749 & 51.03 & 82.840 \\
\hline Bank credit to bank deposits (\%) & 53.847 & 15.162 & 30.38 & 81.050 \\
\hline \multicolumn{5}{|l|}{ Control Variables: } \\
\hline Inflation & 9.1784 & 4.9484 & 2.2697 & 19.749 \\
\hline Openness & 49.658 & 10.178 & 34.846 & 71.681 \\
\hline GDP per capita & 15280 & 2916.9 & 11332 & 19601 \\
\hline Gov. Expenditure & 11.405 & 0.7346 & 10.286 & 12.755 \\
\hline
\end{tabular}

On the other hand, we notice that the variables most related to the percentage of the number of the actual poor in the population in Egypt were the level of trade openness (69.9\%), followed by the level of GDP per capita ($66.9 \%$ ), then the level of inflation (57.5\%), then the ratio of bank credit to bank deposits. (-47.8\%), then the ratio of deposit bank assets to GDP ($39.5 \%$ ), then the ratio of domestic credit provided to the private sector to GDP $(-26.7 \%)$, and finally the level of government spending $(-23.9 \%)$. All of these correlations were statistically significant, with the exception of the variable of the ratio of domestic credit to the private sector to the GDP, the level of government spending, because the link between them and the two poverty indicators was very weak. As for the correlation coefficients between the independent variables and each other, as is evident from the rest of the columns of the table, it came between weak and medium strength, which is a good thing indicating the possibility of no problem (Collinearity). 
Table (2): Correlation matrix between variables

\begin{tabular}{|c|c|c|c|c|c|c|c|c|c|c|}
\hline & & (1) & (2) & (3) & (4) & (5) & (6) & (7) & (8) & (9) \\
\hline $\begin{array}{l}\text { Credit to private sector (\% } \\
G D P)\end{array}$ & (3) & $\begin{array}{l}-0.3061 \\
{[-1.575]}\end{array}$ & $\begin{array}{l}-0.2666 \\
{[-1.355]}\end{array}$ & 1 & & & & & & \\
\hline banks' assets to GDP (\%) & (4) & $\begin{array}{l}-0.4586 \\
{[-2.528]^{* *}}\end{array}$ & $\begin{array}{l}-0.3947 \\
{[-2.105]^{* *}}\end{array}$ & $\begin{array}{l}0.8839 \\
{[9.259]^{* * *}}\end{array}$ & 1 & & & & & \\
\hline credit to deposits (\%) & (5) & $\begin{array}{l}-0.4995 \\
{[-2.824]^{* * *}}\end{array}$ & $\begin{array}{l}-0.4779 \\
{[-2.666]^{* *}}\end{array}$ & $\begin{array}{l}0.9387 \\
{[13.34]^{* * *}}\end{array}$ & $\begin{array}{l}0.8049 \\
{[6.644] * * *}\end{array}$ & 1 & & & & \\
\hline Inflation & (6) & $\begin{array}{l}\mathbf{0 . 6 1 5 2} \\
{[3.823]^{* * *}}\end{array}$ & $\begin{array}{l}0.5751 \\
{[3.444] * * *}\end{array}$ & $\begin{array}{l}-0.6437 \\
{[-4.120]^{* * *}}\end{array}$ & $\begin{array}{l}-0.6827 \\
{[-4.577]^{* * *}}\end{array}$ & $\begin{array}{l}-0.7443 \\
{[-5.461]^{* * *}}\end{array}$ & $\mathbf{1}$ & & & \\
\hline$G D P c$ & $(8)$ & $\begin{array}{l}-0.6054 \\
{[-3.727]^{* * *}}\end{array}$ & $\begin{array}{l}-0.6685 \\
{[-4.404]^{* * * *}}\end{array}$ & $\begin{array}{l}-0.0049 \\
{[-0.024]}\end{array}$ & $\begin{array}{c}0.1061 \\
{[0.523]}\end{array}$ & $\begin{array}{c}0.0875 \\
{[0.430]}\end{array}$ & $\begin{array}{l}-0.0492 \\
{[-0.242]}\end{array}$ & $\begin{array}{l}-0.1792 \\
{[-0.892]}\end{array}$ & 1 & \\
\hline Gov. Exp. & (9) & $\begin{array}{l}-0.2262 \\
{[-1.137]}\end{array}$ & $\begin{array}{l}-0.2385 \\
{[-1.203]}\end{array}$ & $\begin{array}{l}0.6016 \\
{[3.689]^{* * *}}\end{array}$ & $\begin{array}{l}0.6731 \\
{[4.458]^{* * * *}}\end{array}$ & $\begin{array}{l}0.5319 \\
{[3.078]^{* * * *}}\end{array}$ & $\begin{array}{l}-0.3684 \\
{[-1.941]^{*}}\end{array}$ & $\begin{array}{l}-0.0697 \\
{[-0.342]}\end{array}$ & $\begin{array}{c}0.3333 \\
{[1.732]^{*}}\end{array}$ & 1 \\
\hline
\end{tabular}

Note: $-* * *, * *, *$ indicate significance at $1 \%, 5 \%$ and $10 \%$ respectively. 


\section{Econometric analysis and results}

The present study will be used for time series analysis and investigation of the long-term impact of financial development on poverty in Egypt, the Ordinary Least Squares method (OLS). The steps are as follows:

\subsection{Unit Root Test}

Before applying any standard method for estimating the study model, one must first determine the rank of these variables. Among the common tests for detecting stationary time-series that will be used in this study are the Augmented Dickey-Fuller Test (ADF),where is the most widely used test in applied research for stationary detection. Tables (4) and (5) summarize the unit root test results using (ADF) and (PP) test.

Table (4): $A D F-P P$ Unit root test results

\begin{tabular}{|c|c|c|c|c|c|c|}
\hline \multirow[b]{2}{*}{ Variables } & \multicolumn{3}{|c|}{ Level } & \multicolumn{3}{|c|}{ First difference } \\
\hline & Intercept & $\begin{array}{l}\text { Intercept } \\
\text { \& trend }\end{array}$ & None & Intercept & $\begin{array}{c}\text { Interce } \\
\text { pt \& } \\
\text { trend }\end{array}$ & None \\
\hline Poverty gap & $\begin{array}{l}-2.0198 \\
(0.277)\end{array}$ & $\begin{array}{l}-3.5718 \\
(0.059)^{*}\end{array}$ & & & & \\
\hline Poverty headcount & $\begin{array}{l}-1.6420 \\
(0.445)\end{array}$ & $\begin{array}{l}-4.5338 \\
(0.009)^{* * * *}\end{array}$ & & & & \\
\hline $\begin{array}{l}\text { Credit to private sector } \\
(\% G D P)\end{array}$ & $\begin{array}{l}-3.6619 \\
(0.013)^{* *}\end{array}$ & & & & & \\
\hline $\begin{array}{l}\text { Banks' assets to GDP } \\
\text { (\%) }\end{array}$ & $\begin{array}{l}-1.9564 \\
(0.303)\end{array}$ & $\begin{array}{l}-1.8817 \\
(0.633)\end{array}$ & $\begin{array}{r}0.8177 \\
(\mathbf{0 . 8 8 2})\end{array}$ & $\begin{array}{l}-3.3798 \\
(0.022)^{* * *}\end{array}$ & & \\
\hline Credit to deposits (\%) & $\begin{array}{l}-3.8419 \\
(0.008)^{* * * *}\end{array}$ & & & & & \\
\hline Inflation & $\begin{array}{l}-2.6346 \\
(0.099)^{*}\end{array}$ & & & & & \\
\hline
\end{tabular}


Openness $\quad-2.7635$

$(0.079)^{*}$

GDPc $\quad 0.7277 \quad-4.1473$

(0.989) $\quad(0.017) * *$

Gov. Exp. $\quad-1.5841 \quad-1.8116 \quad 0.0994 \quad-4.3158$

$(0.476) \quad(0.669) \quad(0.705)(0.003) * * *$

Note: - ***, **, * indicate significance at $1 \%, 5 \%$ and $10 \%$ respectively.

It is shown from the results of the previous table that the all variables are stationary in level. Exclude Credit to private sector (\% GDP) and government spending, which are stationary in the first difference. So to use OLS technique, we will use these two variables in the first difference.

\subsection{Estimating Study Models:}

After ensuring the quality of the regressions used in the analysis and that they are free from various measurement problems, and this is done by using various diagnostic tests. So we can take a decision can be made of the validity of using these models in estimating the relationships, which are shown in the tables (5). 
Table (5):The Impact of Financial depth on the Poverty

Method: Ordinary Least Squares (OLS) with robust standard errors, variant (HAC)

Dependent variable: Poverty gap\& Poverty headcount ratio at $\$ 1.90$ a day

\begin{tabular}{|c|c|c|c|c|c|c|c|c|}
\hline \multirow[t]{2}{*}{ Independent variable } & \multicolumn{4}{|c|}{ Poverty gap at $\$ 1.90$ a day (2011 PPP) (\%) } & \multicolumn{4}{|c|}{$\begin{array}{c}\text { Poverty headcount ratio at } \$ 1.90 \text { a day (2011 } \\
\text { PPP) } \\
\text { (\% of population) }\end{array}$} \\
\hline & (1) & (2) & (3) & (4) & (5) & (6) & (7) & (8) \\
\hline $\begin{array}{l}\text { Domestic credit to private sector }(\% \text { of } \\
\text { GDP) }\end{array}$ & $\begin{array}{c}-0.007764 \\
{[-2.903]^{* * *}}\end{array}$ & & & $\begin{array}{l}\mathbf{0 . 0 1 1 3 3 7} \\
{[1.666]}\end{array}$ & $\begin{array}{c}-0.050413 \\
{[-2.909]^{* * *}}\end{array}$ & & & $\begin{array}{l}0.073901 \\
{[1.306]}\end{array}$ \\
\hline Deposit money banks' assets to GDP (\%) & & $\begin{array}{c}-0.016072 \\
{[-5.005]^{* * * *}}\end{array}$ & & $\begin{array}{c}-0.019352 \\
{[-5.940]^{* * *}}\end{array}$ & & $\begin{array}{c}-0.084419 \\
{[-3.389]^{* * * *}}\end{array}$ & & $\begin{array}{l}-0.093846 \\
{[-2.471]^{* *}}\end{array}$ \\
\hline Bank credit to bank deposits (\%) & & & $\begin{array}{l}-0.004586 \\
{[-2.283]^{* *}}\end{array}$ & $\begin{array}{l}-0.009102 \\
{[-1.914]^{*}}\end{array}$ & & & $\begin{array}{l}-0.034407 \\
{[-2.765] * *}\end{array}$ & $\begin{array}{l}-0.064122 \\
{[-1.941]^{*}}\end{array}$ \\
\hline Inflation (\%) & $\begin{array}{l}0.004981 \\
{[0.734]}\end{array}$ & $\begin{array}{l}0.001078 \\
{[0.207]}\end{array}$ & $\begin{array}{l}0.008667 \\
{[1.275]}\end{array}$ & $\begin{array}{l}-0.000849 \\
{[-0.175]}\end{array}$ & $\begin{array}{l}0.029665 \\
{[0.675]}\end{array}$ & $\begin{array}{l}0.026754 \\
{[0.663]}\end{array}$ & $\begin{array}{l}0.043007 \\
{[1.022]}\end{array}$ & $\begin{array}{l}0.004387 \\
{[0.155]}\end{array}$ \\
\hline Openness & $\begin{array}{l}0.012095 \\
{[4.734]^{* * * *}}\end{array}$ & $\begin{array}{l}0.011878 \\
{[6.349]^{* * * *}}\end{array}$ & $\begin{array}{l}0.009327 \\
{[3.967]^{* * *}}\end{array}$ & $\begin{array}{l}0.007251 \\
{[2.751]^{* *}}\end{array}$ & $\begin{array}{l}0.086037 \\
{[5.196]^{* * *}}\end{array}$ & $\begin{array}{l}\mathbf{0 . 0 7 9 9 6 3} \\
{[5.509]^{* * *}}\end{array}$ & $\begin{array}{l}0.069279 \\
{[4.759]^{* * * *}}\end{array}$ & $\begin{array}{l}\mathbf{0 . 0 6 1 2 0 8} \\
{[3.359]^{* * * *}}\end{array}$ \\
\hline GDP per capita & $\begin{array}{c}-4.61 \mathrm{e}-05 \\
{[-7.099]^{* * *}}\end{array}$ & $\begin{array}{c}-4.43 \mathrm{e}-05 \\
{[-8.681] * * *}\end{array}$ & $\begin{array}{c}-4.34 \mathrm{e}-05 \\
{[-6.369] * * *}\end{array}$ & $\begin{array}{c}-4.18 \mathrm{e}-05 \\
{[-7.751]^{* * *}}\end{array}$ & $\begin{array}{c}-\mathbf{0 . 0 0 0 3 6 5} \\
{[-8.675]^{* * * *}}\end{array}$ & $\begin{array}{c}-0.000352 \\
{[-8.894]^{* * * *}}\end{array}$ & $\begin{array}{c}-\mathbf{0 . 0 0 0 3 4 8} \\
{[-8.242] * * *}\end{array}$ & $\begin{array}{c}-0.000328 \\
{[-7.211]^{* * *}}\end{array}$ \\
\hline Gov_Exp. & $\begin{array}{l}0.091986 \\
{[2.876]^{* * *}}\end{array}$ & $\begin{array}{l}0.123139 \\
{[4.579]^{* * * *}}\end{array}$ & $\begin{array}{l}0.069794 \\
{[2.237]^{* *}}\end{array}$ & $\begin{array}{l}0.120813 \\
{[5.271]^{* * *}}\end{array}$ & $\begin{array}{l}0.606634 \\
{[2.927] * * *}\end{array}$ & $\begin{array}{l}0.710801 \\
{[3.407]^{* * *}}\end{array}$ & $\begin{array}{l}0.488501 \\
{[2.528]^{* *}}\end{array}$ & $\begin{array}{l}0.660822 \\
{[4.791]^{* * * *}}\end{array}$ \\
\hline Constant & $\begin{array}{l}-0.158055 \\
{[-0.505]}\end{array}$ & $\begin{array}{l}0.324831 \\
{[1.349]}\end{array}$ & $\begin{array}{l}0.108055 \\
{[0.341]}\end{array}$ & $\begin{array}{l}0.858288 \\
{[2.698] * *}\end{array}$ & $\begin{array}{l}-0.219639 \\
{[-0.108]}\end{array}$ & $\begin{array}{l}2.656067 \\
{[1.423]}\end{array}$ & $\begin{array}{l}1.500965 \\
{[0.765]}\end{array}$ & $\begin{array}{l}5.279365 \\
{[2.259]^{* *}}\end{array}$ \\
\hline Adjusted $R^{2}$ & $\% 85.5$ & $\% 90.9$ & $\% 83.7$ & $\% 88.9$ & $\% 88.4$ & $\% 89.5$ & $\% 88.1$ & $\% 90.6$ \\
\hline & $(30.557)^{* * *}$ & $(50.748) * *$ & $(26.640)^{* * * *}$ & $(61.032)^{* * * *}$ & $(39.135)^{* * *}$ & $(43.712) * * *$ & $(37.896) * * *$ & $(35.266)^{* * *}$ \\
\hline
\end{tabular}

Note: $-* * *, * *, *$ indicate significance at $1 \%, 5 \%$ and $10 \%$ respectively.

- [ ] indicate to $t$-statistics. - Numbers without brackets indicate to parametric coefficients.

- HAC standard errors \& covariance (Bartlett kernel, Newey-West fixed bandwidth $=\mathbf{4 . 0 0 0 0}$ ). 
Where the regression (1), (2), (3) represent a study of the effect of each financial development indicator separately on the poverty gap index at the poverty line of $\$ 1.90$ in a day. While equations (5), (6), (7) represent a study of the effect of each financial development indicator separately on the proportion of the number of actual poor in the population at a poverty line of 1.90 dollars per day. While the two regressions (4) and (8) represent the combined effect of the three financial development indicators on the two poverty indicators, respectively. It is evident from the results of the table that most of the variables of the equations were statistically significant in the long term at different levels of significance. Most of the model variables signals are consistent with economic theory, the study hypotheses and the expected signals, and the results of the table can be interpreted as follows:

The results of all equations in the previous table showed a negative impact of financial development with all its indicators used on poverty in Egypt in the long term at a level of $1 \%, 5 \%$ significance. In this way, it is consistent with the study hypothesis and economic theory. It is clear from regression (1) and (5) that an increase in domestic credit to the private sector by $1 \%$ of GDP will lead to a decrease in the poverty gap (\%), and the percentage of the number of actual poor in the population, respectively at a rate of $0.78 \%$ and $5.04 \%$ on average. While regression (2) and (6) show that an increase of $1 \%$ in the deposit money banks' assets to GDP will lead to a decrease in the poverty gap $(\%)$, and the percentage of the number of actual poor in the population, respectively, by $1.6 \%$ and $8.4 \%$ on average. While regressions (3) and (7) show that increasing the bank credit to bank deposits by $1 \%$ will lead to a 
decrease in the poverty gap (\%), and the percentage of the number of actual poor in the population, respectively, by $0.46 \%$ and $3.4 \%$ on average. Thus, it becomes clear that the most used financial development variable affecting the two poverty indicators is the ratio of financial depository banks' assets to the GDP, followed by the ratio of domestic credit to the private sector to GDP, and finally the ratio of bank credit to bank deposits.

Finally, regression (4) and (8) are shown, which include the three indicators of financial development. There was a negative impact of the indicators of the ratio of assets of financial depository banks to the GDP, and the ratio of bank credit to bank deposits on the two poverty indicators used, while the third indicator, which is the ratio of domestic credit to the private sector to the GDP, had no effect on the two poverty indicators.

As for the other explanatory variables, all the equations used in the previous table agreed on the existence of a negative impact for both trade openness and government spending (Gov_Exp.). It is positive for the average GDP per capita $(G D P c)$ on the two poverty indicators used (the poverty gap and the proportion of the number of actual poor in the population at the economic poverty line of 1.90 dollars per day), which is in accordance with the theory and expected signals, except forthe effect of the government spending index, which came opposite What we expect. All the equations also agreed that there was no effect of inflation on poverty in Egypt.

Finally,the key regression statistics show the increase in the value of the modified coefficient of determination $\left(\overline{\mathrm{R}}^{2}\right)$, and the stability of the DWstatistic test value around 2, which confirms the absence of a serial correlation 
between the residuals. Fisher's test (F-Stat) indicates a rejection of the null hypothesis and acceptance of the alternative hypothesis with statistical significance for all the models used atdifferent levels of significance.

\section{Conclusion:}

The financial depth and poverty nexus had received a considerable attention over time, on both theoretical and empirical literature. Recent development in this area have heightened the awareness for determining the appropriate indicators for measuring financial depth, and the channels through which financial depth influence economic growth and poverty. The estimated results confirmed the existence of long run equilibrium relationship between financial depth, economic growth,and poverty reduction in Egypt. Our results show that financial sector development plays a vital role in facilitating economic growth in Egypt. A sound financial system supports economic growth through mobilizing and pooling savings. This contributes to poverty reduction through a major channel that is through economic growth. 


\section{Reference:}

ADB. 2004. Impact Evaluation Study on ADB's Rural Credit Assistance in Bangladesh, People's Republic of China (PRC), Indonesia, Nepal, Philippines, Sri Lanka, and Thailand. Asian Development Bank, Manila.

Abosedra, S., Shahbaz, M. \& N., 2015. Modeling Causality Between Financial Deeping and poverty Reduction in Egypt. Social Indicators Research, 1 (1), pp. $1-15$.

Abu-Bader, S. \& Abu-Qarn, A., 2005. Financial Development and Economic Growth: Time Serious Evidence from Egypt.

Abu-Bader, S. \& Abu-Qarn, A., 2008. Financial Development and Economic Growth: The Egyptian Experience. Journal of Policy Modeling, 30(5), p. 887898.

AbulEyoun, M., 2003. Monetary policy in Egypt: A Vision For The Future, Cairo: Egyptian Center for Economic Studies.

Aghion, P., and P. Bolton. 1997. "A Theory of Trickle-Down Growth and Development." Review of Economic Studies 64:151-72.

Aghion, P., and P. Howitt. 1992. "A Model of Growth through Creative Destruction." Econometrica60:323-51.

Ali, I. and J. Zhuang. 2007. Inclusive Growth toward a Prosperous Asia: Policy Implications. ERD Working Paper Series No. 97, Economics and Research Department, Asian Development Bank, Manila.

Arner, D. 2007. Financial Stability, Economic Growth, and the Role of Law. New York: Cambridge University Press.

Ayyagari, M., A. Demirgüç-Kunt, and V. Maksimovic. 2006. How Important Are Financing Constraints? The Role of Finance in the Business Environment. World Bank Policy Research Working Paper No. 3820. World Bank, Washington, DC. 
Banerjee, A. 2009. Lin Roundtable: Difficult Trade-offs. Free Exchange, Economist.com blogs.

Available:

www.economist.com/blogs/freeexchange/lin_roundtable.

Banerjee, A., and A. Newman. 1993. "Occupational Choice and the Process of Development." Journal of Political Economy 101(2):274-98.

Banerjee, A., E. Duflo, R. Glennerster, and C. Kinnan. 2009. The Miracle of Microfinance? Evidence from a Randomized Evaluation. Paper prepared under a research partnership between the Abdul Latif Jameel Poverty Action Lab at MIT and the Center for Microfinance at IFMR.

Barth, J., G. Caprio, and R. Levine. 2004. "Bank Regulation and Supervision: What Works Best?" Journal of Financial Intermediation 13:205-48.

Beck, T. 2006. Creating an Efficient Financial System: Challenges in a Global Economy. World Bank Policy Research Working Paper No. 3856, World Bank, Washington, DC.

Bolbol, A. A., Fatheldin, A. \& Omran, M. M., 2005. Financial Development, Structure, and Economic Growth: The Case of Egypt, 1974 2002. Research in International Business and Finance, 19(1), p. 171-194.

Caprio, G., and M. Martinez-Peria. 2002. "Avoiding Disasters: Policies to Reduce the Risk of Banking Crises." In E. Cardoso and A. Galal, eds., Monetary Policy and Exchange Rate

Regimes: Options for the Middle East. The Egyptian Center for Economic Studies, Cairo,

Egypt.

Chaiechi, T., 2014. Post-Keynesian Empirical Research and the Debate on Financial Market Development. 1st ed. Hershey, PA, USA: IGI Global. 
Christen, R. P. 2004. "Struggling Through the "Growth versus Best Practice" Tradeoff: The CrediAmigo Program of the Banco de Nordeste, Brazil." In CGAP, Scaling Up Poverty Reduction: Case Studies in Microfinance. Global Learning Process for Scaling Up Poverty Reduction Conference in Shanghai, Washington, DC, 25-27 May.

Claessens, S. 2005. "Theories of Currency and Banking Crises: A Literature Review." In ADB eds., Early Warning System for Financial Crises: Applications to East Asia. London: Palgrave.

Claessens, S., and E. Feijen. 2006. Financial Sector Development and the Millennium

Development Goals. World Bank Working Paper No. 89, World Bank, Washington, DC.

Claessens, S., and L. Laeven. 2005. "Financial Sector Competition, Finance Dependence, and Economic Growth." Journal of the European Economic Association 3(1):179-207.

Coleman, B. 2006. "Microfinance in Northeast Thailand: Who Benefits and How Much?” World Development 34(9):1612-38.

Dollar, D., and A. Kraay. 2002. "Growth is Good for the Poor." Journal of Economic Growth 7(3):195-225.

Dupas, P., and J. Robinson. 2009 Saving Constraints and Microenterprise Development: Evidence from a Field Experiment in Kenya. NBER Working Paper No. w14693, National Bureau of Economic Research, Cambridge, MA.

Dyer, J., J. P. Morrow, and R. Young. 2004. The Agricultural Bank of Mongolia. In Consultative Group to Assist the Poor. Scaling Up Poverty Reduction: Case 
Studies in Microfinance.Global Learning Process for Scaling Up Poverty Reduction Conference in Shanghai, Washington, DC, 25-27 May.

Easterly, W., R. Islam, and J. Stiglitz. 2000. "Shaken and Stirred: Explaining Growth Volatility.” In Macroeconomic Paradigms for Less Developed Countries. World Bank, Washington, DC.

Elazhary, Ramy. 2018. "The Impact of the Financial Depth on the Rate of Economic Growth in Egypt". PhD diss. University of Zagzig.

Elsayed, A. H., 2013. The Relationship between Financial System Development and Economic Growth in the Egyptian Economy, Leeds, UK: White Rose, eTheses Online.

Fry. M. J., 1978. Money and Capital or Financial Deepening in Economic

Development?. Journal of Money, Credit, and Banking, 10(4), pp. 464-475.

Fry, M. J., 1980. Money, Interest, Inflation, and Growth in Turkey. Journal of Monetary Economics, 6(4), pp. 535-545.

Fry, M. J., 1989. Financial Development: Theories And Recent Experience.

Oxford Review of Economic Policy, 5(4), pp. 13-28.

Galor, O., and D. Tsiddon. 1996. "Income Distribution and Growth: The Kuznets Hypothesis Revisited." Economica63:S103-17.

Galor, O., and J. Zeira. 1993. "Income Distribution and Macroeconomics." The Review of Economic Studies 60(1):35-52.

Goldsmith, R. W. 1969. Financial Structure and Development. New Haven, CT: Yale University Press.

Honohan, P. 2004a. "Financial Development, Growth and Poverty: How Close are the Links?" In E. C. Goodhard, ed., Financial Development and Economic Growth: Explaining the Links. London: Palgrave. 
Hosny, A. S., 2012. Financial Development and Economic Growth in Egypt. Macroeconomics and Finance in Emerging Market Economies, 5(1), p. 60-75.

Jalilian, H., and C. Kirkpatrick. 2005. "Does Financial Development Contribute to Poverty

Reduction?” Journal of Development Studies 41(4):636-56.

Kakwani, N. 2000. "On Measuring Growth and Inequality Components of Poverty with Application to Thailand." Journal of Quantitative Economics 16:67-79.

Keynes, J. M., 1936. The General Theory of Employment Interest and Money. $1^{\text {st }}$ ed. London: Macmillan.

Levine, R. 2004. Finance and Growth: Theory and Evidence. NBER Working Paper No. 10766, National Bureau of Economic Research, Cambridge, MA. Available: www.nber.org/papers/ w10766.

Lucas, R. 1988. "On the Mechanics of Economic Development." Journal of Monetary Economics 22:3-42.

Romer, P. M. 1986. "Increasing Returns and Long-run Growth." Journal of Political Economy 94(5):1002-37.

Stiglitz, J. E., and A. M. Weiss. 1981. "Credit Rationing in Markets with Perfect Information." American Economic Review 71(3):393-410.

Tutulmaz, O., 2014. Monetary Growth Models: An Evaluation on Tobin Model. Journal of Social Sciences Research, Volume Vol. 6, No. 2, pp. 1017-1022.

World Bank Group, 2017. Doing Business 2017: Equal Opportunity for All, Washington, DC: The World Bank.

World Bank, 2014. Global Financial Structure Matter?. Washington, DC., The World Bank; 
تتناول هذه الدراسة الروابط بين العمق المالي والحد من الفقر في مصر باستخدام البيانات في الفترة من ( 1990-2015) ، وطبقت الدر اسة طريقة المربع الأخير (OLS) لفحص تأثير العمق المالي على الحد من الفقر. واعتمدت الدراسة في التعبير عن المنغير التابع لهاوهو مستوى الفقر على متغيرين أصليين: فجوة الفقر ، ونسبة عدد الفقراء الفعليين من السكان ، عند خط الفقر البالغ (1.90) دولار في اليوم ، بحسب إلى 2011 تعادل القوة الثرائية. أما بالنسبة للمتغير المستهدف المستقل الذي لدينا وهو التنمية المالية ، فستعتمد الدراسة على ثلاثة متغيرات وكيل للتعبير عن مستوى التطور المالي، من أجل التحقق من متانة النتائج وموثوقيتها ، وهي الائتمان المحلي للقطاع الخاص ( ٪ من الناتج المحلي الإجمالي) ، و أصول بنوك الإبداع المالية إلى الناتج المحلي الإجمالي (\%) ، بالإضافة إلى الائتمان المصرفي للودائع المصرفية (\%). تظهر نتائجنا دليلاً على التكامل المشترك الذي يؤكد وجود علاقة طويلة المدى بين العمق المالي و النمو الاقتصادي و الحد من الفقر. الكلمات الرئيسية: التتمية المالية؛ العمق المالي؛ الفقر. 